\title{
Blood Cells Indices are Determinants of the COVID-19 Outcome: A Cross-Sectional Study from Kurdistan Region-Iraq
}

\author{
Marwan S.M. Al-Nimer ${ }^{1,2 \star}$, Talar Ahmad Merza ${ }^{2}$, Karwan Yasin Mohammed Yasin Mohammed ${ }^{3}$, \\ Hiwa Abdullah Mohammed ${ }^{3}$
}

\author{
${ }^{1}$ College of Medicine, University of Diyala, Baqubah, IRAQ \\ ${ }^{2}$ College of Pharmacy, Hawler Medical University, Kurdistan Region, Erbil, IRAQ \\ ${ }^{3}$ West Erbil Emergency Hospital (Corona Center), Kurdistan Region, Erbil, IRAQ \\ *Corresponding Author: alnimermarwan@ymail.com
}

Citation: Al-Nimer MSM, Merza TA, Mohammed KYMY, Mohammed HA. Blood Cells Indices are Determinants of the COVID-19 Outcome: A CrossSectional Study from Kurdistan Region-Iraq. Electron J Gen Med. 2021;18(5):em304. https://doi.org/10.29333/ejgm/11013

\section{ARTICLE INFO}

Received: 16 Mar. 2021

Accepted: 18 May 2021

\begin{abstract}
Introduction: The complete blood picture of patients with COVID-19 showed lymphocytopenia and neutrophilia. Changes in the circulating blood cells are served as prognostic factors of COVID-19. This study aimed to investigate the clinical importance of determining the hematological indices and ratios as diagnostic and/or prognostic markers of COVID-19.
\end{abstract}

Methods: This cross-sectional observational study was performed in the West Erbil Emergency Hospital, Kurdistan region, Erbil- Iraq, between August 10 and November 19, 2020. A total of 204 patients with COVID-19 were included in this study. The hematological indices and their derived ratios were determined, C-reactive protein and the outcome events were the primary outcome measures.

Results: The mean value of leukocytes is $\geq 10,000 \mathrm{cell} / \mathrm{mm}^{3}$, which characterized by neutrophilia and lymphocytopenia. The percentage of monocyte is significantly higher in patients with hypertension with and without diabetes mellitus compared with other patients. There are no significant differences between patients with and without concomitant diseases in the erythrocyte sedimentation rate and C-reactive protein. The mortality rate was $31.3 \%$ (64 out of 204). Red distribution width and neutrophil-to-lymphocyte ratio are significant discriminators of the non-survivor patients with COVID-19 (The area under the curve with $95 \%$ confidence interval: $0.618(0.510-0.726)$ and $0.612(0.505-0.718)$, with odd ratios of $3.02,2.407$, at cutoff values $\geq 13.2 \%$ and 12.0$)$, respectively.

Conclusion: Significant high values of red distribution width and lymphocyte-to-neutrophil ratio are associated with unpleasant outcome events of COVID-19 patients, while a higher percentage of monocyte is commonly found in hypertensive patients presented with COVID-19.

Keywords: COVID-19, hematological indices and ratios, outcome, hypertension, diabetes mellitus

\section{INTRODUCTION}

COVID-19 is a pandemic viral disease caused by a coronavirus (CoV), presented with respiratory and extrarespiratory signs and symptoms. Polymerase chain replication technology is the definite laboratory tool for the diagnosis of $\mathrm{CoV}$ infections. The hematological indices are also useful in the diagnosis and assessment of COVID-19. Lymphocytes and monocytes are part of immune system, which specifically determine the immune response to the foreign substances and microorganisms, while the main function of the neutrophils is protecting the humans from bacterial infections. Lymphocytopenia is commonly reported in COVID-19 patients $[1,2]$, and other studies found that lymphocytopenia is a prognostic marker as $35-75 \%$ of patients who had lymphocytopenia did not survive [3]. Also, another study reported that patients who were admitted to the intensive care unit had a cutoff value of lymphocyte count $<0.6 \times 10^{9} / L$ [4].
Lymphcytopenia observed in severe COVID-19 disease is significantly characterized by a lower number of CD4+ and $\mathrm{CD} 8+$, and usually associated with a significant increase of Creactive protein, D-dimer and interleukins (including IL-2R, IL$6, \mathrm{IL}-10)$ and tumor necrosis factor- $\alpha[5]$

A small percentage of patients with severe illness showed a leukocyte count $>10,000 / \mathrm{mm}^{3}$ which is due to a higher number of lymphocytes or neutrophils or both [1]. A significant high neutrophil count is an indication of the bacterial superinfection, cytokine storm, and hyperinflammatory state that accompanied CoV infections [6-8]. Moreover, the neutrophil-to-lymphocyte ratio (NLR) is significantly increased in severe COVID-19 compared with those with mild-illness [8]. The majority of patients showed significant low platelet count and linked with severe infection and hypoxia [9-11]. Mean platelet volume (MPV) was found to be increased in COVID-19 with unfavorable outcomes (death or venous thrombosis) compared with patients who survived without thrombosis complication [12]. Another retrospective study, including 85 


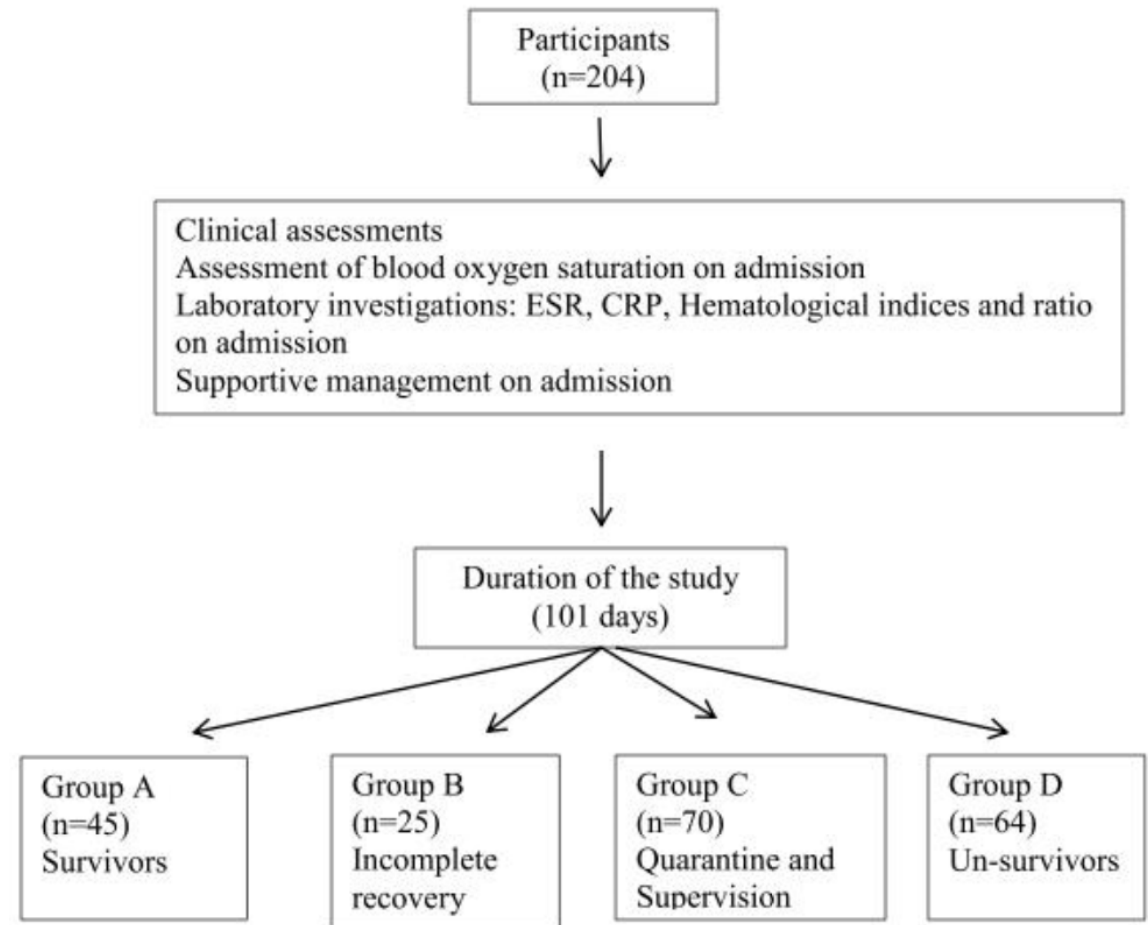

Figure 1. Distribution of COVID-19 according to the outcomes

COVID-19 patients, found that patients with severe pneumonia had a significant MPV-to platelet count ratio, which can be considered as an independent risk factor for severe pneumonia [13]. The rationale of this study is that the hematological indices can give a typical pattern of viral infection, specifically for CoV infections. Also, it can be applied to discriminate and predict the survivals of COVID-19 patients. This cross-sectional study aimed to investigate the clinical importance of determining the hematological indices as diagnostic and prognostic markers in a small sample of the Kurdistan population taking into consideration the concomitant diseases and the outcome events.

\section{MATERIALS AND METHODS}

\section{Design and Setting}

This cross-sectional study included adult patients of both sexes hospitalized in the West Erbil Emergency Hospital, Kurdistan region, Erbil- Iraq, between August 10 and November 19, 2020. The West Erbil Emergency Hospital was established for quarantine and management of COVID-19 in the Kurdistan region, with 102 beds, thirty-four physicians, ten pharmacists, 224 nurses, specialized laboratories and radiological departments for diagnosis of $\mathrm{CoV}$ infections, and the facilities of artificial ventilation.

The diagnosis of COVID-19 was confirmed by polymerase chain reaction (PCR) assays on the swabs obtained from the nasopharynx. The Ethical and Scientific Board at the Ministry of the Heath in the Erbil approved this study, and exempt the need for consent.

\section{Sample Size}

The sample size was calculated using $\alpha$-coefficient (type II error) $=0.05, \beta$-coefficient (type l error) $=0.2$, and power $=85 \%$ ). The patients were randomly recruited from the hospital using a random numbers table according to the number of admission sheet records.

\section{Participants}

A total number of 204 patients were allocated from singlecenter (128 males and 76 females, with a mean age of 58.3 years). Current illnesses were reported in 19 (9.3\%) patients with diabetes mellitus; 45 (22.1\%) patients with hypertension; $80(39.2 \%)$ patients with hypertension and diabetes mellitus; and $4(2 \%)$ patients with blood disorders. We categorized the patients into four categories according to their outcomes (Figure 1):

Group A: patients who recovered from illness and discharged from the hospital.

Group B: patients who were discharged from the hospital with minor clinical features (dry cough, fatigue, etc.) without any evidence of clinical and radiological investigations that indicate the presence of any complications).

Group C: Patients with clinical features of COVID-19 and required quarantine in the hospitals to avoid future complications. Some of these patients required oxygen therapy.

Group D: Patients who died (non-survivors) in the intensive care unit. Most patients admitted to the intensive care unit (ICU) required oxygen therapy and ventilator support.

Group A represented the survivors while Group D represented non-survivor patients.

\section{Determination of Clinical Variables}

On admission, samples of the blood obtained from patients under careful precautions and sent to the laboratories of the hospital to determine the hematological indices (blood samples with EDTA as an anticoagulant), and quantitative serum C-reactive protein (separated serum from a blood sample without EDTA). Neutrophil-to-lymphocyte (NLR) and platelet-to lymphocyte (PLR) ratios were simply calculated by 
Table 1. Analysis of hematological indices data according to the presence of concomitant diseases

\begin{tabular}{|c|c|c|c|c|c|c|c|c|}
\hline \multirow{2}{*}{ Variables } & \multirow{2}{*}{$\begin{array}{c}\text { Non- } \\
\text { hypertensive } \\
\text { non-diabetes } \\
(n=60)\end{array}$} & \multirow{2}{*}{$\begin{array}{l}\text { Hypertensive } \\
\text { non-diabetes } \\
\quad(n=45)\end{array}$} & \multirow{2}{*}{$\begin{array}{l}\text { Diabetes non- } \\
\text { hypertensive } \\
\quad(n=19)\end{array}$} & \multirow{2}{*}{$\begin{array}{l}\text { Hypertensive } \\
\text { and diabetes } \\
\quad(n=80)\end{array}$} & \multicolumn{2}{|c|}{$\begin{array}{c}\text { Analysis of } \\
\text { variance }\end{array}$} & \multicolumn{2}{|c|}{$\begin{array}{c}\text { Homogeneity of } \\
\text { variance }\end{array}$} \\
\hline & & & & & F-value & $P$-value & $\begin{array}{c}\text { Levene } \\
\text { statistics }\end{array}$ & $P$-value \\
\hline Age (year) & $46.3(1.5)$ & $58.8(1.9)$ & $55.9(2.1)$ & $67.6(1.2)$ & 40.186 & .001 & 1.083 & .358 \\
\hline Sex $(M: F)$ & $40: 20$ & $26: 19$ & $12: 7$ & $50: 30$ & & & & \\
\hline RBC count $\left(\times 10^{6} / \mathrm{mm}^{3}\right)$ & $4.8(0.08)$ & $4.6(0.1)$ & $4.6(0.2)$ & $4.7(0.1)$ & 0.770 & .512 & 1.297 & .277 \\
\hline $\mathrm{Hb}(\mathrm{g} / \mathrm{dL})$ & $13.5(0.2)$ & $13.1(0.3)$ & $12.7(0.5)$ & $12.9(0.2)$ & 1.566 & .199 & 0.997 & .395 \\
\hline Hct (\%) & $40.5(0.8)$ & $39.6(1.1)$ & $38.3(1.3)$ & $39.1(0.6)$ & 0.836 & .476 & 0.638 & .591 \\
\hline $\mathrm{MCH}(\mathrm{pg})$ & $28.5(0.4)$ & $28.5(0.4)$ & $27.8(0.7)$ & $27.8(0.3)$ & 1.174 & .321 & 0.455 & .714 \\
\hline $\mathrm{MCHC}(\mathrm{g} / \mathrm{dL})$ & $33.2(0.2)$ & $33.1(0.2)$ & $33.1(0.4)$ & $33.0(0.2)$ & 0.206 & .892 & 0.746 & .526 \\
\hline $\mathrm{MCV}(\mathrm{fL})$ & $85.7(1.1)$ & $86.2(1.1)$ & $84.0(2.2)$ & $84.2(0.7)$ & 0.950 & .418 & 0.969 & .408 \\
\hline RDW (\%) & $13.2(0.2)$ & $13.5(0.2)$ & $12.9(0.2)$ & $13.4(0.2)$ & 1.048 & .372 & 0.806 & .492 \\
\hline \multirow{4}{*}{$\begin{array}{c}\text { WBC count } \\
\left(\times 10^{3} / \mathrm{mm}^{3}\right) \\
\text { Neutrophil }(\%) \\
\text { Lymphocyte }(\%)\end{array}$} & $14.8(0.8)$ & $13.8(1.0)$ & $15.1(1.9)$ & $12.8(0.6)$ & 1.299 & .276 & 1.049 & .372 \\
\hline & $85.4(1.1)$ & $81.2(1.2)$ & $85.7(1.3)$ & $83.2(1.0)$ & 2.413 & .068 & 2.852 & .038 \\
\hline & $8.3(0.6)$ & $8.2(0.7)$ & $8.1(0.8)$ & $7.8(0.5)$ & 0.134 & .940 & 0.100 & .960 \\
\hline & $13.8(0.9)$ & $12.8(1.0)$ & $13.2(1.8)$ & $13.6(0.7)$ & 0.140 & .936 & 0.096 & .962 \\
\hline \multirow{3}{*}{$\begin{array}{c}\text { NLR } \\
\text { Monocyte (\%) } \\
\text { Eosinophil (\%) } \\
\text { Basophil (\%) } \\
\end{array}$} & $5.5(0.8)$ & $9.4(1.1)$ & $5.0(1.0)$ & $8.0(0.9)$ & 3.327 & .021 & 7.865 & $<.001$ \\
\hline & $0.8(0.1)$ & $1.1(0.2)$ & $1.1(0.3)$ & $0.8(0.1)$ & 0.941 & .422 & 3.344 & .020 \\
\hline & $0.1(0.0)$ & $0.2(0.0)$ & $0.2(0.1)$ & $0.1(0.0)$ & 1.222 & .303 & 4.258 & .006 \\
\hline \multirow{5}{*}{$\begin{array}{l}\text { Platelet count } \\
\left(\times 10^{3} / \mathrm{mm}^{3}\right)\end{array}$} & $251.5(15.2)$ & $255.9(19.0)$ & $247.3(31.0)$ & $246.6(15.1)$ & 0.056 & .983 & 0.358 & .784 \\
\hline & $0.2(0.01)$ & $0.2(0.02)$ & $0.2(0.02)$ & $0.2(0.01)$ & 0.103 & .959 & 0.315 & .815 \\
\hline & $8.9(0.1)$ & $9.0(0.1)$ & $9.1(0.2)$ & $9.0(0.1)$ & 0.187 & .905 & 1.109 & .347 \\
\hline & $42.7(0.9)$ & $40.8(1.4)$ & $40.7(2.3)$ & $42.3(0.8)$ & 0.727 & .537 & 1.607 & .189 \\
\hline & $37.3(2.9)$ & $39.3(3.7)$ & $38.6(9.6)$ & $38.6(2.8)$ & 0.052 & .984 & 0.572 & .634 \\
\hline
\end{tabular}

The results are expressed as number and mean (standard error). RBC: red blood cell, Hb: hemoglobin, Hct: hematocrit, $\mathrm{MCH}$ : mean corpuscular hemoglobin, MCHC: mean cell hemoglobin concentration, MCV: mean cell volume, RDW: red distribution width, WBC: white blood cell, NLR: neutrophil-to-lymphocyte ratio, PCT: plateletcrit, MPV: mean platelet volume, PDW: platelet distribution width, PLR: platelet-to-lymphocyte ratio.

Table 2. Distribution of the patients according to their outcomes categories

\begin{tabular}{ccccc}
\hline Category & $\begin{array}{c}\text { Non-hypertensive non- } \\
\text { diabetes } \\
(\mathbf{n = 6 0 )}\end{array}$ & $\begin{array}{c}\text { Hypertensive } \\
(\mathbf{n = 4 5 )}\end{array}$ & $\begin{array}{c}\text { Diabetes mellitus } \\
\mathbf{( n = 1 9 )}\end{array}$ & $\begin{array}{c}\text { Hypertensive and } \\
\text { diabetes } \\
(\mathbf{n = 8 0})\end{array}$ \\
\hline A & $22(36.7)$ & $8(17.8)$ & $3(15.8)$ & $12(15.0)$ \\
\hline B & $5(8.3)$ & $6(13.3)$ & $4(21.1)$ & $10(12.5)$ \\
\hline C & $18(30.0)$ & $19(42.2)$ & $5(26.3)$ & $28(35.0)$ \\
\hline D & $15(25.0)$ & $12(26.7)$ & $7(36.8)$ & $30(37.5)$ \\
\hline Total & $60(100)$ & $45(100)$ & $19(100)$ & $64(31.3)$ \\
\hline
\end{tabular}

The results expressed as number (percentage). Category A: recovery, Category B: Discharge without complete recovery, Category C: quarantine in the hospital with signs and symptoms, Category D: death

dividing the neutrophils or platelets count as numerators by the lymphocytes count as a denominator.

\section{Statistical Analysis}

The results are expressed as a number, percentage, and mean \pm SE. The data were statistically analyzed using a twotailed, one-way analysis of variance (ANOVA), homogeneity test of variance (Levene's statistics), receiving operating characteristics, and calculating the risk odd ratios for continuous data, and Chi-square test for categorized data. Pvalue $\leq 0.05$ is a lower significance level. SPSS-20 (IBMcompatible) was applied for statistical analysis.

\section{RESULTS}

Distribution of Hematological Indices and Ratios According to the Presence of Concomitant Diseases

A total number of 204 patients were included in this study. The number of male patients was non-significantly $\left(X^{2}=0.873\right.$, $P=.832$ ) higher than the corresponding female patients, and the mean age of the patients with concomitant diseases was higher than patients without concomitant diseases (Table 1). There is no significant difference in the red cell indices in patients with or without concomitant diseases. The red cell indices were within the normal range. White cell indices showed the mean values are $\geq 10.000 \mathrm{cell} / \mathrm{mm}^{3}$, which characterized by a higher percentage of neutrophil and a lower percentage of lymphocyte in each patient group with or without concomitant diseases. The percentage of monocyte is significantly higher in patients with hypertension with and without diabetes mellitus compared with other patients. The mean values of the blood platelet indices are within normal limits, and the platelet count was higher than the lower limit of normal platelet count $\left(150,000 / \mathrm{mm}^{3}\right)$. Moreover, the data showed homogeneity in the variance of each patients group except the percentages of the granulocytes (monocyte, eosinophil, and basophil), which are significantly showed heterogeneity.

\section{The Outcomes of Patients According to the Concomitant Illnesses}

Table 2 shows that the mortality rate was 31.3\% (64 out of 204). Patients with concomitant diseases constituted the higher number of Groups C and D. Diabetic patients were more 
Table 3. Assessment of saturated oxygen percentage $\left(\mathrm{SPO}_{2}\right)$, erythrocyte sedimentation rate $(\mathrm{ESR})$ and $\mathrm{C}$-reactive protein (CRP) at the time of presentation with COVID-19

\begin{tabular}{|c|c|c|c|c|c|c|c|c|}
\hline \multirow[b]{2}{*}{ Variables } & \multirow{2}{*}{$\begin{array}{c}\text { Non-hypertensive } \\
\text { non-diabetes } \\
(n=60)\end{array}$} & \multirow[b]{2}{*}{$\begin{array}{l}\text { Hypertensive } \\
\quad(n=45)\end{array}$} & \multirow{2}{*}{$\begin{array}{c}\text { Diabetes } \\
\text { mellitus } \\
(n=19)\end{array}$} & \multirow{2}{*}{$\begin{array}{c}\text { Hypertensive and } \\
\text { diabetes } \\
(n=80)\end{array}$} & \multicolumn{2}{|c|}{ ANOVA-test } & \multicolumn{2}{|c|}{ Homogeneity } \\
\hline & & & & & F-value & $P$-value & $\begin{array}{c}\text { Levene } \\
\text { statistics }\end{array}$ & $P$-value \\
\hline $\mathrm{SPO}_{2}(\%)$ & $81.3(1.4)$ & $84.8(1.5)$ & $76.4(3.5)^{\star}$ & $80.3(1.2$ & 2.895 & .036 & 1.591 & .193 \\
\hline ESR $(\mathrm{mm} / \mathrm{h})$ & $66.1(3.5)$ & $69.8(3.6)$ & $72.1(6.6)$ & $70.4(2.6)$ & 0.453 & .715 & 0.642 & .589 \\
\hline CRP (mg/L) & $85.9(8.9)$ & $93.1(10.4)$ & $98.9(19.5)$ & $98.8(8.4)$ & 0.391 & .760 & 0.503 & .680 \\
\hline
\end{tabular}

The results are expressed as mean (standard error). * Significant difference with hypertensive patients.

Table 4. Comparisons between COVID-19 patients who recovered from the disease and patients who died according to the hematological indices

\begin{tabular}{|c|c|c|c|c|c|c|}
\hline \multirow{2}{*}{ Variables } & \multirow{2}{*}{ Recovery } & \multirow{2}{*}{ Death } & \multicolumn{2}{|c|}{ Analysis of variance } & \multicolumn{2}{|c|}{ Analysis of homogeneity } \\
\hline & & & F-value & $P$-value & Levene statistic & $P$-value \\
\hline RDW & $13.2(0.2)$ & $13.7(0.2)$ & 3.535 & .063 & 0.717 & .399 \\
\hline PDW & $41.6(1.2)$ & $41.4(1.2)$ & 0.010 & .921 & 1.079 & .301 \\
\hline MPV & $8.9(0.1)$ & $9.190 .1)$ & 1.042 & .310 & 3.894 & .051 \\
\hline NLR & $12.0(1.0)$ & $14.4(0.8)$ & 3.247 & .074 & 1.253 & .265 \\
\hline PLR & $36.4(3.2)$ & $39.6(2.5)$ & 0.632 & .428 & 0.083 & .773 \\
\hline
\end{tabular}

The results are expressed as mean \pm standard error. RDW: red distribution width, PDW: platelet width distribution, MPV: mean platelet volume, NLR: neutrophil-to-lymphocyte ratio, and PLR: platelet-to-lymphocyte ratio.

likely to have unfavorable outcomes compared with hypertensive (36.8\% versus $26.7 \%$ ). On admission, diabetic patients had a lower percentage of saturated oxygen compared with others (Table 3 ), which is significantly less than the corresponding value of non-hypertensive non-diabetic patients $(76.4 \pm 3.5 \%$ versus $81.3 \pm 1.4 \%)$. During the course of COVID-19, there are no significant differences between patients with and without concomitant diseases in the erythrocyte sedimentation rate and C-reactive protein, accounting for significantly higher values compared with normal upper limits (Table 3).

\section{Comparison between Category A and D Regarding Hematological Indices}

There are non-significant statistical differences between patients related to the categories $A$ and $D$ regarding the mean values of red distribution width (RDW), platelet distribution width (PDW), MPV, NLR, and PLR. The data of these hematological indices and ratios showed homogeneity as Levene's statistic value was non-significant for each index and ratio (Table 4). Moreover, the RDW and the NLR ratio are significant discriminators of the unfavorable event (death) of patients with COVID-19 (Figure 2). The areas under the curve with 95\% C.I. of the RDW and NLR are $0.618(0.510-0.726)$ and 0.612 (0.505-0.718), respectively (Figure 2). The odd ratios of unfavorable (death) outcomes are 3.02, 2.407, and 2.407 at cutoff values of RDW ( $\geq 13.2$ ), NLR (12.0), and PLR (36.8), respectively (Figure 3 ).

\section{DISCUSSION}

The results of this study indicate that the determination of hematological indices and ratios at the time of hospitalization can predict the outcome events of COVID-19 patients despite the presence or absence of concomitant diseases, including hypertension and/or diabetes mellitus. The characteristic hematological profile of COVID-19 is neutrophilia, lymphocytopenia, a higher monocyte percentage, and within the normal range of the blood platelet count. The results of this study are in parallel with previous studies that neutrophilia and lymphocytopenia are the characteristic features of CoV infection. Terpos et al. [14] reported that lymphocytopenia occurred after 7-14 days from the clinical presentation of the COVID-19, and considered as a prognostic factor. The causes of lymphocytopenia are due to the lysis of the lymphocyte as a result of binding the CoV to the angiotensin converting enzyme receptor -2 (ACER-2) which is expressed on the lymphocyte [15], and to the inflammatory mediators that released as a part of cytokine storm syndrome, which cause lymphocyte apoptosis [16-18], and atrophy of lymphoid tissue [19]. A higher number of the leucocytes $\left(>10,000 / \mathrm{mm}^{3}\right)$, is also a feature of COVID-19, and it may indicate superimposed secondary infection [20]. The percentage of monocyte is higher among hypertensive patients with/without type 2 diabetes mellitus. Merad and Martin [21] reported that dysregulation of the immune system as a result of hyperinflammation leads to an increase in the number of monocyte/macrophage in the bronchoalveolar fluid in severe COVID-19. This work demonstrates a significantly higher percentage of circulating monocyte in the peripheral blood, which is linked to hypertensive patients rather than to the severity of COVID-19. The explanation of this observation that peripheral monocytes are activated the vascular endothelium under the effect of excess production of IL- 6 and deprivation of nitric oxide in hypertension [22]. It is well known that CoV cannot cause direct damage to the blood platelet because the platelets lack ACER2 on their surfaces [14]. Thrombocytopenia is a feature of severe COVID-19, and it is usually noted in the non-survivors [23]. On the other side, COVID-19 patients who had a peak platelet count at the time of clinical presentation will have a worse prognosis [24]. Moreover, concomitant diseases are not the cause of the changes in the blood platelet indices of COVID19 patients (Table 1 ). The results of hematological ratios during the course of illness explore their important values to discriminate and predict the patients who may be nonsurvivors. Red distribution width significantly discriminates the non-survivor from survivor COVID-19 (Figure 2), and COVID-19 patients who had an $\mathrm{RDW} \geq 13.2 \%$ will get a poor prognosis. This observation wasn't previously mentioned. The neutrophilto-lymphocyte ratio is significantly higher in non-survivors compared with survivor patients, which this finding agreed 


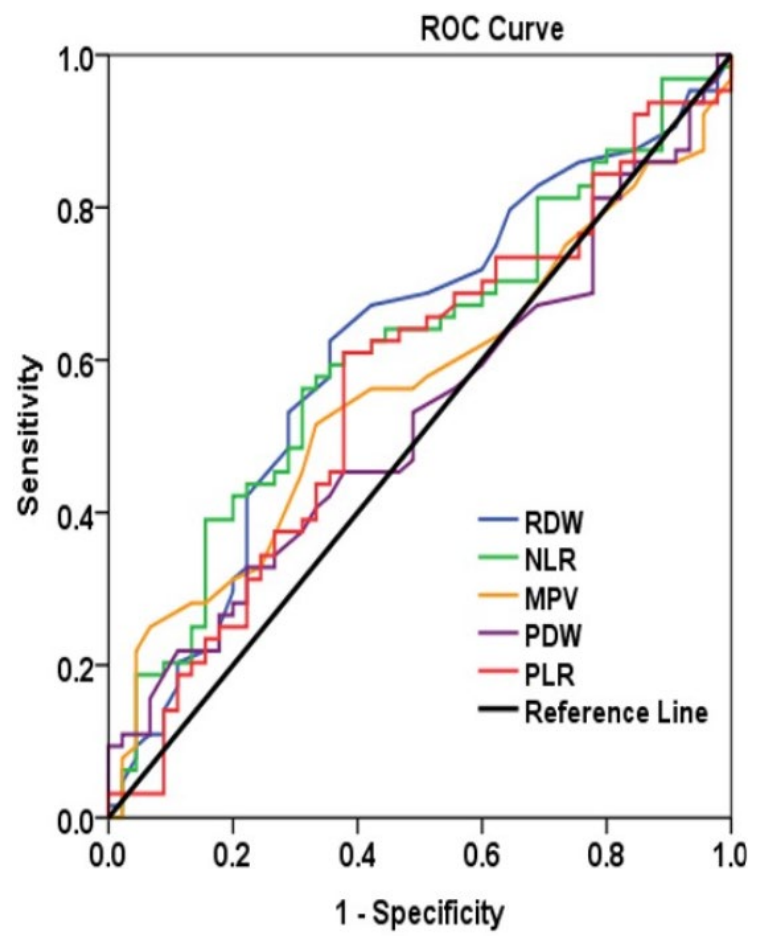

Diagonal segments are produced by ties.

\begin{tabular}{|l|l|l|l|l|}
\hline Test Result Variable(s) & Area & $\begin{array}{c}\text { Standard } \\
\text { error }\end{array}$ & p-value & $\begin{array}{c}\text { 95\% Confidence } \\
\text { Interval }\end{array}$ \\
\hline Red distribution width (CV) & 0.618 & 0.055 & 0.037 & $0.510-0.726$ \\
\hline Neutrophil-to-lymphocyte ratio & 0.612 & 0.054 & 0.048 & $0.505-0.718$ \\
\hline Mean platelet volume & 0.561 & 0.055 & 0.276 & $0.454-0.669$ \\
\hline Platelet distribution width (\%) & 0.526 & 0.055 & 0.647 & $0.417-0.634$ \\
\hline Platelet-to-lymphocyte ratio & 0.567 & 0.056 & 0.236 & $0.457-0.677$ \\
\hline
\end{tabular}

Figure 2. The area under the curve of the hematological indices in dead patients compared with recovered patients from COVID19

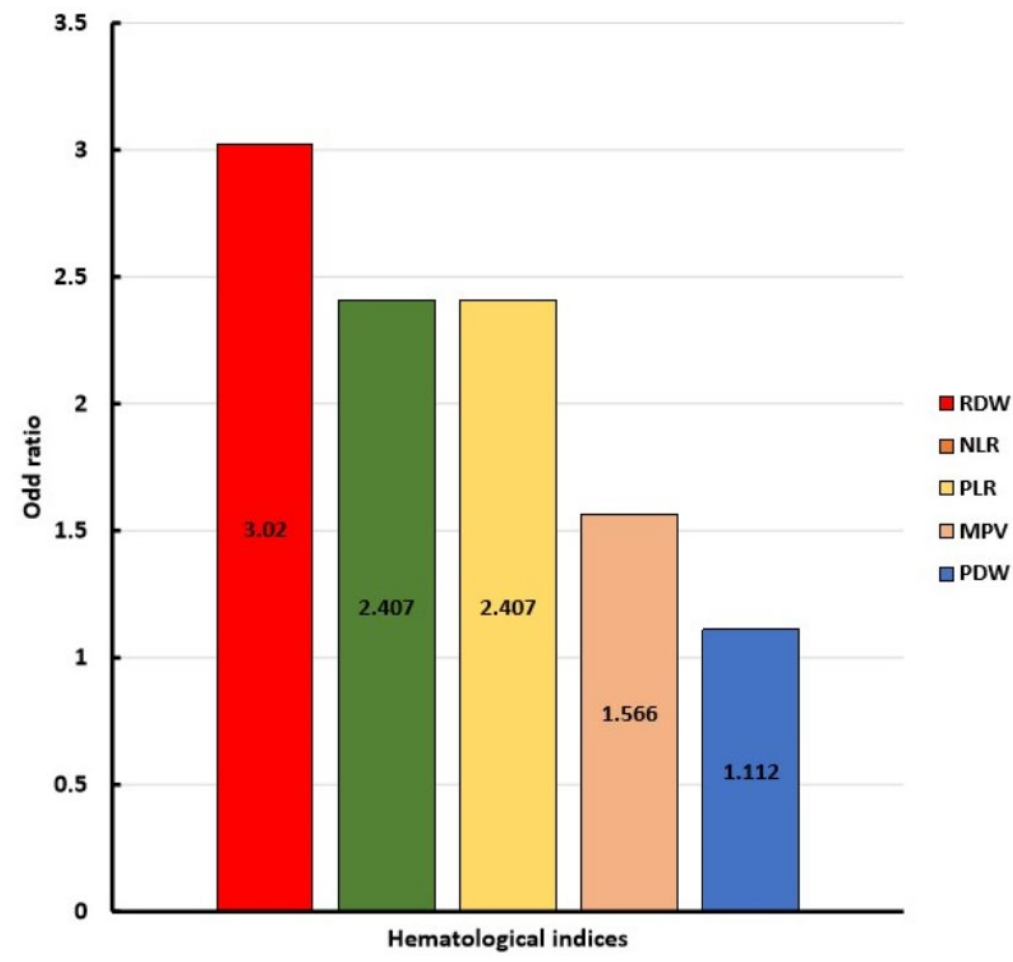

Figure 3. Odd ratios of hematological indices of unfavorable outcome (death) using cutoff median values of survival patients. Cutoff values of RDW, NLR, PLR, MPV, and PDW are: $\geq 13.2,12.0,247.3,9.0$, and 43.3. RDW: red distribution width (CV), NLR: neutrophil-to-lymphocyte ratio, PLR: platelet-to-lymphocyte ratio, MPV: mean platelet volume, and PDW: platelet width distribution (\%). 
with previous studies [25]. This work adds two important findings that the NLR can discriminate against the nonsurvivors from recovered patients (Figure 2), and the NLR value of $\geq 12.0$ during the course of illness predicts the non-survivor (odds ratio: 2.407 ). The PLR at a cutoff value of 36.8 can predict the non-survivors of COVID-19 patients. This observation agreed with other studies that patients with a higher PLR ratio are at risk of worse prognosis [24,25]. Mean platelet volume and platelet distribution width can predict the non-survivors as their odd ratios exceeded 1.0 but they are not discriminated against the non-survivors. This study agreed with another study that observed each one femtolitre increment of the MPV will increase the mortality rate by 1.76 [26]. Higher values of serum CRP and ESR indicate that COVID-19 patients were presented with hyperinflammation, which is prescribed in a lot of studies. Also, a low mean value of blood saturated indicates that hospitalization of the patients is absolutely indicated, and a significantly low $\mathrm{PSO}_{2}$ in diabetes patients may be due to the small sample size. Limitations of the study included the variability in the duration of the disease (from the onset of clinical presentation to the hospitalization), serial measurements of complete blood count, and a small sample size of diabetic patients. The strength of this study is related to describing the cutoff values of hematological indices and ratios.

We conclude that the determination of hematological indices and ratios during the course of illness can serve as discriminators and predictors of patients who will get a poor prognosis. A significantly higher percentage of monocyte during the course of COVID-19 is a feature of hypertensive patients.

Author contributions: MS-AN provided the study concept and design statistical analysis, data management, and wrote the manuscript. TAM provided the design, recruited the patients, and performed data management. KYM recruited the patients, and HWM made the applications of laboratory investigations. All authors critically reviewed the manuscript.

Funding: The Ministry of Health and Haler Medical University in Kurdistan-Region, Iraq supported this study

Acknowledgements: The authors express their thanks to The Ministry of Health and the Hawler Medical University at Kurdistan Region-Iraq, for giving us the facilities to do the most important study which is not free from the risk of contamination.

Declaration of interest: The authors declare that they have no competing interests.

Availability of data and material: The datasets used and analyzed during the current study are available from the corresponding author on reasonable request.

\section{REFERENCES}

1. Lippi G, Plebani M. The critical role of laboratory medicine during coronavirus disease 2019 (COVID19) and other viral outbreaks. Clin Chem Lab Med 2020;58(7):1063-69. https://doi.org/10.1515/cclm-2020-0240 PMid:32191623

2. Huang C, Wang Y, Li X, et al. Clinical features of patients infected with 2019 novel coronavirus in Wuhan, China. Lancet 2020;395(10223):497-506. https://doi.org/10.1016/ S0140-6736(20)30183-5

3. Lippi G, Plebani M. Laboratory abnormalities in patients with COVID-2019 infection. Clin Chem Lab Med 2020; 58(7):1131-34. https://doi.org/10.1515/cclm-2020-0198 PMid:32119647
4. Fan BE, Chong VCL, Chan SSW, et al. Hematologic parameters in patients with COVID-19 infection. Am J Hematol 2020; 95(6):E131-E4. https://doi.org/10.1002/ ajh.25774 PMCid:PMC7267477

5. Chen G, Wu D, Guo W, et al. Clinical and immunological features of severe and moderate coronavirus disease 2019. J Clin Invest 2020;130(5):2620-9. https://doi.org/10.1172/ JCI137244 PMid:32217835 PMCid:PMC7190990

6. Chen N, Zhou M, Dong X, et al. Epidemiological and clinical characteristics of 99 cases of 2019 novel coronavirus pneumonia in Wuhan, China: a descriptive study. Lancet 2020;395(10223):507-13. https://doi.org/10.1016/S01406736(20)30211-7

7. Mehta P, McAuley DF, Brown M, et al. COVID-19: consider cytokine storm syndromes and immunosuppression. Lancet 2020;395(10229):1033-4. https://doi.org/10.1016/ S0140-6736(20)30628-0

8. Qin C, Zhou L, Hu Z, et al. Dysregulation of immune response in patients with COVID-19 in Wuhan, China. Clin Infect Dis 2020;71(15):762-8. https://doi.org/10.1093/cid/ ciaa248 PMid:32161940 PMCid:PMC7108125

9. Lippi G, Plebani M, Henry BM. Thrombocytopenia is associated with severe coronavirus disease 2019 (COVID19) infections: A meta-analysis. Clin Chim Acta. 2020;506:145-8. https://doi.org/10.1016/j.cca.2020.03.022 PMid:32178975 PMCid:PMC7102663

10. Yang AP, Liu JP, Tao WQ, Li HM. The diagnostic and predictive role of NLR, d-NLR and PLR in COVID-19 patients. Int Immunopharmacol 2020;84:106504. https://doi.org/ 10.1016/j.intimp.2020.106504 PMid:32304994 PMCid: PMC7152924

11. Zou Z, Yang Y, Chen J, et al. Prognostic factors for severe acute respiratory syndrome: a clinical analysis of 165 cases. Clin Infect Dis 2004;38(4):483-9. https://doi.org/10.1086/ 380973 PMid:14765339 PMCid:PMC7107942

12. Barrett TJ, Lee AH, Xia Y, et al. Platelet and vascular biomarkers associate with thrombosis and death in coronavirus disease. Circ Res 2020;127(7):945-7. https://doi.org/10.1161/CIRCRESAHA.120.317803 PMid:32757722 PMCid:PMC7478197

13. Zhong Q, Peng J. Mean platelet volume/platelet count ratio predicts severe pneumonia of COVID-19. J Clin Lab Anal 2020:e23607. https://doi.org/10.1002/jcla.23607

14. Terpos E, Ntanasis-Stathopoulos I, Elalamy I, et al. Hematological findings and complications of COVID-19. Am J Hematol 2020;95(7):834-47. https://doi.org/10.1002/ ajh.25829 PMid:32282949 PMCid:PMC7262337

15. Xu H, Zhong L, Deng J, Peng J, Dan H, Zeng X, Li T, Chen Q. High expression of ACE2 receptor of2019-nCoV on the epithelial cells of oral mucosa. Int J Oral Sci 2020; 12(1):8. https://doi.org/10.1038/s41368-020-0074-x PMid:32094336 PMCid:PMC7039956

16. Singh S, Sharma A, Arora SK. High producer haplotype (CAG) of-863C/A,-308G/A and -238G/A polymorphisms in the promoter region of TNF-alpha gene associate with enhanced apoptosis of lymphocytes in HIV-1 subtype C infected individuals from North India. PLoS One 2014;9(5):e98020. https://doi.org/10.1371/journal.pone. 0098020 PMid:24837009 PMCid:PMC4024031

17. Liao YC, Liang WG, Chen FW, Hsu JH, Yang JJ, Chang MS. IL19 induces production of IL- 6 and TNF-alpha and results in cell apoptosis through TNF-alpha. J Immunol 2002;169(8): 4288-97. https://doi.org/10.4049/jimmunol.169.8.4288 PMid:12370360 
18. Aggarwal S, Gollapudi S, Gupta S. Increased TNF-alphainduced apo-ptosis in lymphocytes from aged humans: changes in TNF-alpha receptor expression and activation of caspases. J Immunol 1999;162(4):2154-61. PMID:9973490

19. Chan JF, Zhang AJ, Yuan S, et al. Simulation of the clinical and pathological manifestations of Coronavirus Disease 2019 (COVID-19) in golden Syrian hamster model: implications for disease pathogenesis and transmissibility. Clin Infect Dis 2020;71(9):2428-46. https://doi.org/ 10.1093/cid/ciaa325 PMid:32215622 PMCid:PMC7184405

20. Li X, Xu S, Yu M, et al. Risk factors for severity and mortality in adult COVID-19 inpatients in Wuhan. J Allergy Clin Immunol 2020;146(1):110-8. https://doi.org/10.1016/ j.jaci.2020.04.006 PMid:32294485 PMCid:PMC7152876

21. Merad M, Martin JC. Pathological inflammation in patients with COVID-19: a key role for monocytes and macrophages. Nat Rev Immunol. 2020;20(6):355-362. https://doi.org/ 10.1038/s41577-020-0331-4 PMid:32376901 PMCid: PMC7201395

22. Loperena R, Van Beusecum JP, Itani HA, et al. Hypertension and increased endothelial mechanical stretch promote monocyte differentiation and activation: roles of STAT3, interleukin 6 and hydrogen peroxide. Cardiovasc Res 2018;114(11): 1547-63. https://doi.org/10.1093/cvr/cvy112 PMid:29800237 PMCid:PMC6106108
23. Guo T, Fan Y, Chen M, et al. Cardiovascular implications of fatal out-comes of patients with coronavirus disease 2019 (COVID-19). JAMA Cardiol 2020;5(7):811-8. https://doi.org/ 10.1001/jamacardio.2020.1017 PMid:32219356 PMCid: PMC7101506

24. Qu R, Ling Y, Zhang YH, et al. Platelet-to-lymphocyte ratio is associated with prognosis in patients with coronavirus disease-19. J Med Virol. 2020;92(9):1533-41. https://doi.org /10.1002/jmv.25767 PMid:32181903 PMCid:PMC7228291

25. Yang M, Ng MH, Li CK. Thrombocytopenia in patients with severe acute respiratory syndrome (review). Hematology 2005;10(2):101-5. https://doi.org/10.1016/j.intimp.2020. 106504 PMid:32304994 PMCid:PMC7152924

26. Güçlü E, Kocayiğit H, Okan HD, et al. Effect of COVID-19 on platelet count and its indices. Rev Assoc Med Bras (1992) 2020;66(8):1122-7. https://doi.org/10.1590/1806-9282.66.8. 1122 PMid:32935808 